\title{
Comparative Antimicrobial Effect of Boswellia, Lichen, Coffea peel, Asafoetida, Saussurea Costus, Rhatany, Anise and Cumin Extracts on Some Animal Pathogens
}

\author{
Rehab Mohamed Atta El-Desoukey ${ }^{1 *}$, Afrah H. Al-Qahtani², Anwar A. Al- \\ Oatibi í , Amal H. Al-Qahtani ${ }^{2}$, Ashwaq A. Al-Qahtani ${ }^{2}$, Wadha S. Al-Qahtani², \\ Ohood S. Al-Oatibi², Nushata M Al-Qahtani ${ }^{2}$ and Mishail Q Al-Oatibi ${ }^{2}$ \\ ${ }^{1}$ Microbiology and Immunology Department, National Research Center, Egypt \\ ${ }^{2}$ Biology Department, Faculty of Science and humanities in Al Quwai'iyah; Shaqraa University, \\ Kingdom of Saudi Arabia
}

\section{Research Article}

Volume 5 Issue 1

Received Date: July 14, 2020

Published Date: July 17, 2020

DOI: 10.23880 /oajvsr-16000193

*Corresponding author: Rehab Mohamed Atta El-Desoukey, Biology Department, Faculty of Science and humanities in Al Quwai'iyah; Shaqraa University, Kingdom of Saudi Arabia, Email: rehab.eldesoukey@gmail.com

\section{Abstract}

Numerous plants have so far been utilized for the treatment and the executives of different illnesses since the start of human development. One of the regular issues in the clinical world, spreading of bacterial opposition against anti-infection agents, so one of the most significant strides in microbiological investigates is to locate another antimicrobial compound with insignificant reactions. Because of the nearness of organic dynamic mixes in plant and herbs and its utilization in conventional Objective medication and sustenance, it appears that this plants and herbs contain limit significant antimicrobial. So the aim of this study is to explore the antimicrobial action of Boswellia, Lichen, Coffea peel, Rhatany (Krameria triandra), Cuminum cyminum, Pimpinella anisum, Asafoetida, and Saussurea costus aqueous and solvent extracts on some therapeutically significant bacteria and fungi isolated from animals. Hot and cold aqueous extracts in addition to alcohol extracts of Boswellia, Lichen, Coffea peel, Rhatany (Krameria triandra), Cuminum cyminum, Pimpinella anisum, Asafoetida, and Saussurea costus were assessed for their antimicrobial effect against Streptococcus, Escherichia coli Salmonella, klebsiella and Candida albicans by agar well diffusion method. Every single examined plants and herbs indicated antibacterial impact against examined pathogenic microscopic organisms particularly Rhatany, Asafoetida, Lichen, and Pimpinella anisum. The lesser impact was for Coffea peel. Also the most antifungal action against Candida albican swas for Rhatany. For the most part the viable concentrate was the cold aqueous extract for all analyzed plants and herbs.

Keywords: Boswellia; Lichen; Coffea peel; Asafoetida; Saussurea costus; Rhatany; Anise; Cumin; Antimicrobial

\section{Introduction}

Organisms are the most widely recognized reason for irresistible sicknesses which take an interest in about portion of the passings in human and animals. Just as horribleness and mortality because of loose bowels in many creating nations which go about as a significant issue, The diseases because of assortment of bacterial etiologic operators, for example, pathogenic Escherichia coli (E. coli), Salmonella spp., and Staphylococcus aureus (S. aureus) are generally normal [1]. Also foundational mycotic diseases because of Candida albicans (C.albicans) have risen as significant reasons for 


\section{Open Access Journal of Veterinary Science \& Research}

dreariness and mortality [2].

Anti-infection opposition has become a worldwide concern. As multi-tranquilize safe pathogen for the most part influence the clinical adequacy of many existing antimicrobials [3]. Throughout the historical backdrop of humankind numerous irresistible maladies have been known to be treated with home grown cures where restorative plants despite everything go about as the most widely recognized wellspring of antimicrobial specialists. This conventional wellbeing cures use is the most mainstream for $80 \%$ of total populace everywhere throughout the world and was accounted for to have negligible symptoms Pharmacological or organic tests have been submitted to roughly $20 \%$ of the plants found on the planet. A consistent exertion is finished by the microbiologists utilizing the foundational screening of antimicrobial plant concentrates to discover new mixes can possibly act against multidrug safe pathogenic microscopic organisms and fungi [4].

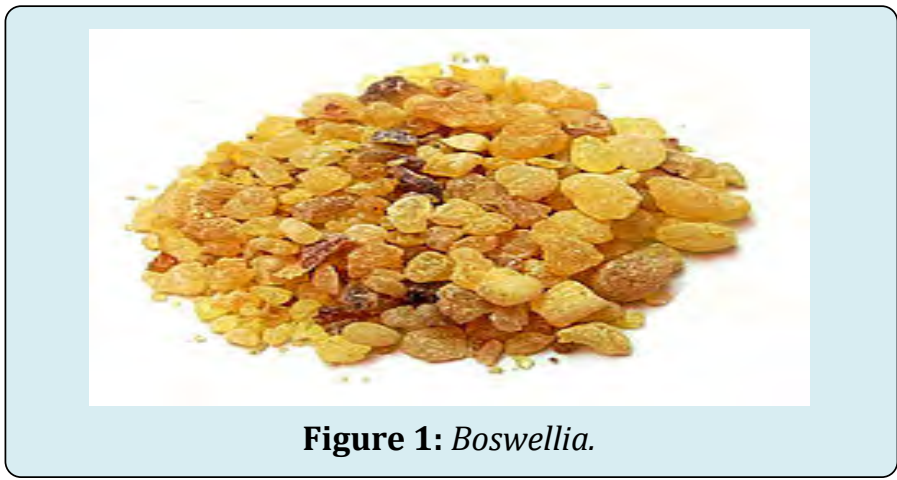

Boswellia species are moderate-sized blooming plants, including the two trees and bushes, and are local to tropical areas of Africa and Asia. The conveyances of the species are fundamentally connected with the tropics. The best decent variety of species by and by is in Africa and India [5].

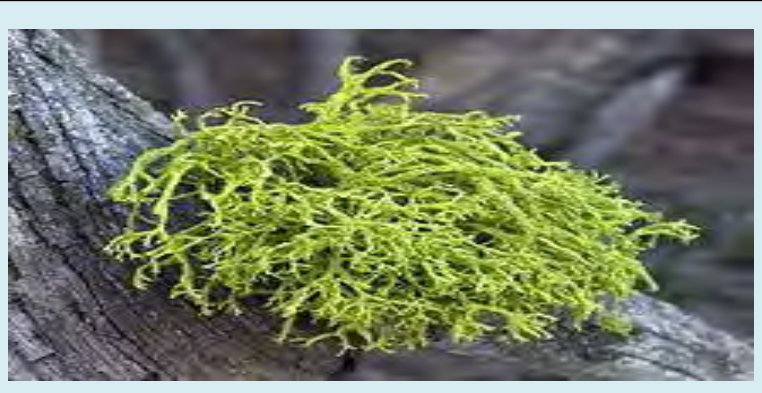

Figure 2: Lichen.

A Lichen is a composite living being that emerges from green growth or cyanobacteria living among fibers of different fungi species in a mutualistic relationship [6].
Lichens come in numerous hues, sizes, and structures. The properties are in some cases plant-like, yet Lichens are not plants. Lichens may have small, leafless branches (fruticose), level leaf-like structures (foliose), chips that lie on a superficial level like stripping paint (crustose) [7], a powder-like appearance (leprose), or other development forms [8]. Lichens produce metabolites in research for their likely restorative or symptomatic worth. A few metabolites delivered by Lichens are fundamentally and practically like wide range anti-microbials while few are related separately to germ-free similarities [9], Usnic corrosive is the most normally considered metabolite created by Lichens. It is likewise under exploration as a bactericidal specialist against Escherichia coli and Staphylococcus aureus [10].

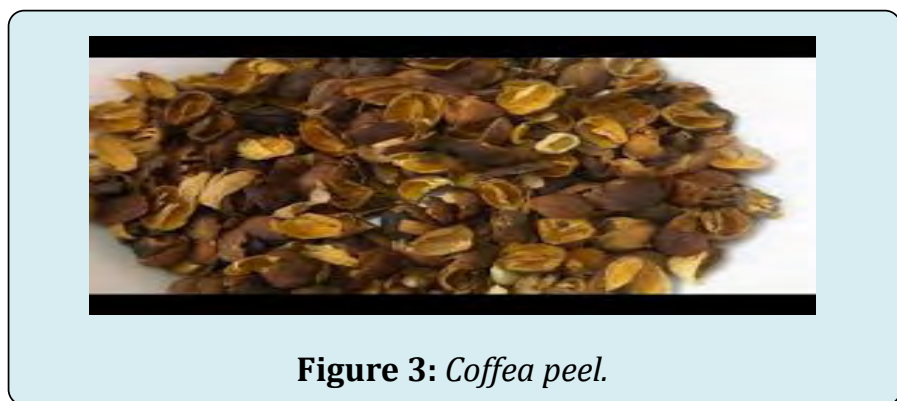

Coffea is a sort of blooming plants in the family Rubiaceae Coffea species are bushes or little trees local to tropical and southern Africa and tropical Asia. The seeds of certain species, called espresso beans, are utilized to enhance different refreshments and items. The organic products, similar to the seeds, contain a lot of caffeine, and have an unmistakable sweet taste and are frequently squeezed. The plant positions as one of the world's generally significant and broadly exchanged item crops and is a significant fare result of a few nations, incorporating those in Central and South America, the Caribbean and Africa [11].

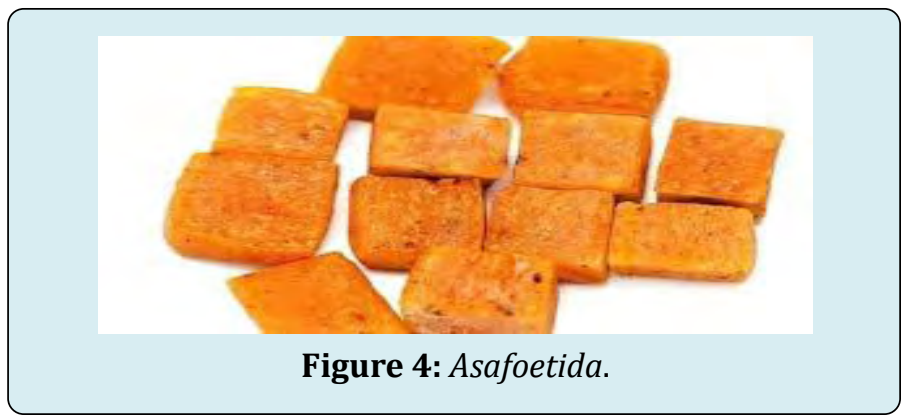

Asafoetida is the dried latex (gum oleoresin) oozed from the rhizome or tap foundation of a few types of Ferula, a lasting herb that grows 1 to $1.5 \mathrm{~m}$ ( 3.3 to $4.9 \mathrm{ft}$ ) tall. It is a piece of the celery family Apiaceae and was utilized as a less expensive substitute for that verifiably significant herb. The 


\section{Open Access Journal of Veterinary Science \& Research}

species is local to the deserts of Iran and heaps of Afghanistan, however is for the most part developed in close by India [12]. Asafoetida has an impactful smell, subsequently its paltry name smelling gum, however in cooked dishes it conveys a smooth flavor suggestive of leeks. It is otherwise called food of the divine beings, villain's dung [13].

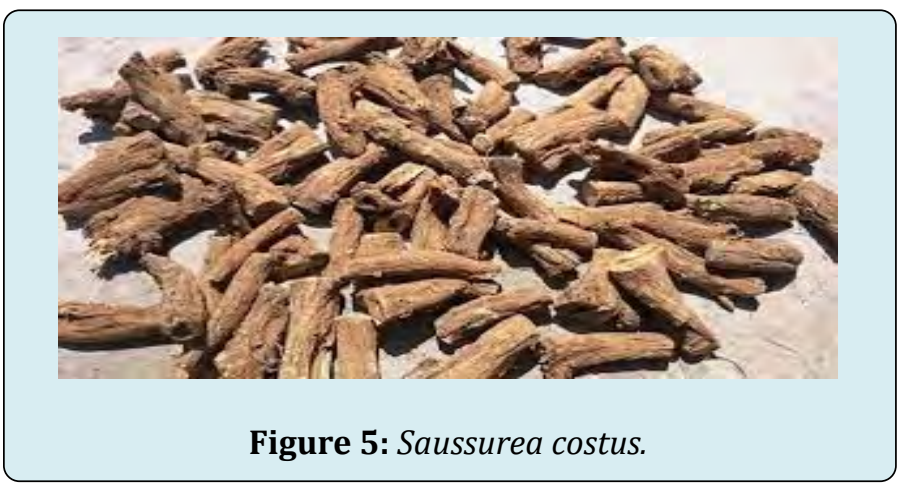

Saussurea costus, regularly known as costus or kuth, is types of thorn in the class Saussurea local to India. Fundamental oils extricated from the root have been utilized in conventional medication and in scents since old times [14]. The class Saussurea has a place with Asteraceae which includes around 300 species in the realm of which 61 species are found in India. The foundation of the plant is the key part utilized for restorative or homeopathic purposes [15].

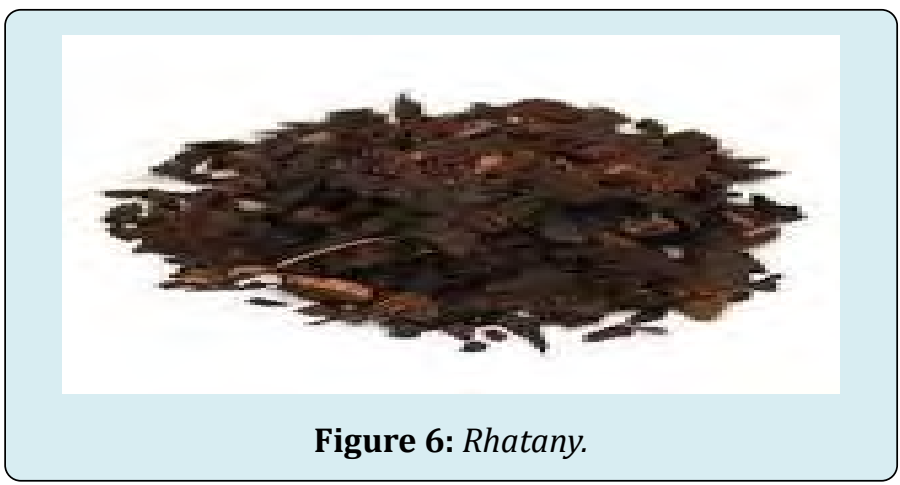

Rhatany (Krameria triandra) is a plant that is genuinely extraordinary. The root is utilized as medication. Related plants (other Krameria species) are some of the time subtly added to Rhatany arrangements to grow the measure of item gave. Individuals take Rhatany for intestinal growing (enteritis) and chest torment (angina) [16]. Rhatany is here and there utilized as a mouthwash or wash for mellow mouth and throat bothering, swollen gums, split tongue, and blister. It is likewise applied to the skin for leg ulcers and for expanding and irritation brought about by cold and soggy climate (chilblains). Rhatany contains high centralizations of tannins. Astringent synthetics, for example, tannins, can decrease irritation by contracting tissues and pus [17].

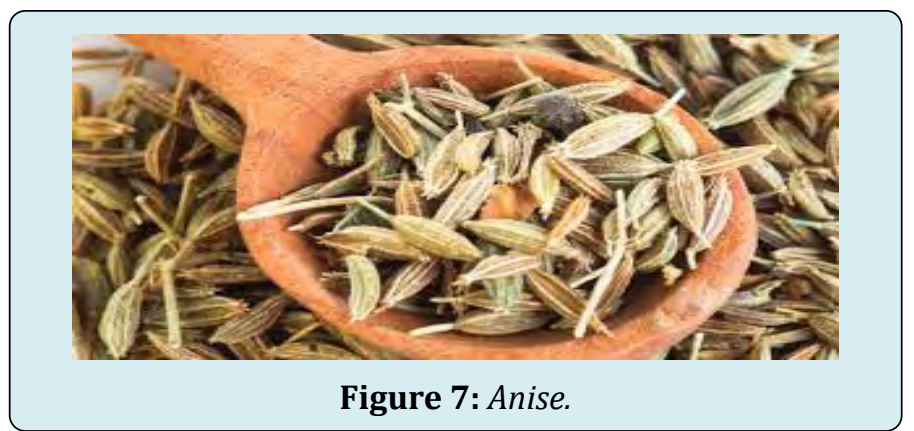

Anise (Pimpinella anisum), additionally called aniseed is a blooming plant in the family Apiaceae local toward the eastern Mediterranean area and Southwest Asia [18]. Its flavor has likenesses with some different flavors, for example, star anise, fennel, and liquorice. It is broadly developed and used to enhance food and mixed beverages, particularly around the Mediterranean. It filled in as a carminative in home grown medication [19].

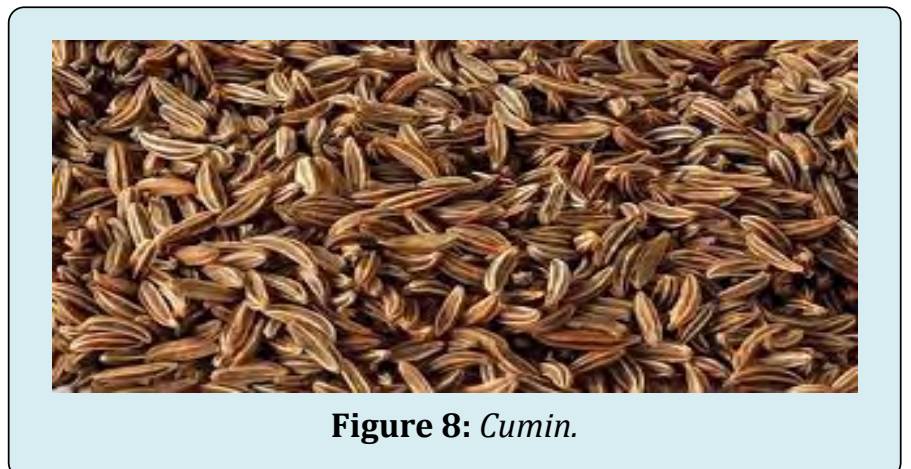

Cumin (Cuminum cyminum) is a blooming plant in the family Apiaceae, local to a domain including the Middle East and extending east to India. Its seeds - everyone contained inside a natural product, which is dried - are utilized in the cooking styles of numerous societies in both entire and ground structure. In spite of the fact that cumin is thought to have utilizes in customary medication, there is no excellent proof that it is protected or viable as a restorative agent [20]. So the aim of this study is to investigate the antimicrobial activity of Boswellia, Lichen, Coffea peel, Rhatany (Krameria triandra), Cuminum cyminum, Pimpinella anisum, Asafoetida, and Saussurea costus aqueous and solvent extracts on some medically important bacteria and fungi.

\section{Materials and Methods}

\section{Collection of Plant Materials}

New pounded fine powder plant and herbs materials were bought from markets in Quiyeia/ KSA.

\section{Aqueous Extraction}

Around $10 \mathrm{ml}$ of each hot and cold distilled water was
Rehab Mohamed Atta El-Desoukey, et al. Comparative Antimicrobial Effect of Boswellia, Lichen, Coffea peel, Asafoetida, Saussurea Costus, Rhatany, Anise and Cumin Extracts on Some Animal Pathogens. J Vet Sci Res 2020, 5(1): 000193.
Copyright(C) Rehab Mohamed Atta El-Desoukey, et al. 


\section{Open Access Journal of Veterinary Science \& Research}

added to $5 \mathrm{~g}$ of the chose plant or herb in sterile test tubes. The tubes were saved for multi week at room temperature until use.

\section{Solvent Extraction}

Around $5 \mathrm{~g}$ of dried plant material was extricated with $10 \mathrm{~mL}$ of dissolvable (Ethanol) saved for $24 \mathrm{~h}$. At that point, it was sifted utilizing whattman channel paper. The dissolvable was dissipated to make the last volume as $1 / 2$ of the first volume [21].

\section{Preparation of Inoculums}

The strains of microscopic organisms (Streptococcus, Salmonella, Klebsiella and E. coli) and fungi (C. albicans) were immunized in Sabaroud dextrose agar and supplement stock for the time being at $37^{\circ} \mathrm{C}$ for bacteria and $25^{\circ} \mathrm{C}$ for fungi. At that point as a corroborative strategy, E.coli and Salmonella was refined on MacConkey agar and C. albicans on potato dextrose agar for $48 \mathrm{hr}$ at $37^{\circ} \mathrm{C}$ for E.coli and Salmonella and at $25^{\circ} \mathrm{C}$ for Candida.

\section{Antimicrobial Screening}

The fundamental investigation of antimicrobial effect of various extracts of Boswellia, Lichen, Coffea peel, Rhatany (Krameria triandra), Cuminum cyminum, Pimpinella anisum, Asafoetida, and Saussurea costus was performed by utilizing agar well diffusion method [22]. The affectability of all extracts was tried against (Streptococcus, Salmonella, Klebsiella and E. coli) and fungi (C. albicans) the hostile to microbial action was estimated by the inhibitory zones created in millimeter. All tests were copied. Ciprofloxacin $(10 \mu \mathrm{g})$ and penicillin $(10 \mu \mathrm{g})$ utilized as positive control while distilled water $(100$ $\mu \mathrm{g})$ utilized as negative control for antibacterial screening. Nystatin $(10 \mu \mathrm{g})$ was utilized as positive control while distilled water $(100 \mu \mathrm{g})$ utilized as negative control for antifungal screening.

\section{Results}

\begin{tabular}{|c|c|c|c|c|c|c|c|c|c|c|c|c|}
\hline \multirow{2}{*}{ Isolates } & \multirow{2}{*}{$\begin{array}{c}\text { Aqueous } \\
\text { and } \\
\text { solvent } \\
\text { extracts }\end{array}$} & \multicolumn{8}{|c|}{ Examined Herbs and Plants } & \multirow{2}{*}{\begin{tabular}{|c|}
$\begin{array}{c}\text { Antibacterial } \\
\text { control } \\
\text { positive }\end{array}$ \\
ciprofloxacin \\
\end{tabular}} & \multirow{2}{*}{\begin{tabular}{|c|}
$\begin{array}{c}\text { Antifungal } \\
\text { control } \\
\text { positive }\end{array}$ \\
Nystatin
\end{tabular}} & \multirow{2}{*}{\begin{tabular}{|c}
$\begin{array}{c}\text { Antimicrobial } \\
\text { control } \\
\text { negative }\end{array}$ \\
$\begin{array}{c}\text { Distilled } \\
\text { water }\end{array}$
\end{tabular}} \\
\hline & & Boswellia & Lichen & $\begin{array}{c}\text { Coffea } \\
\text { peel }\end{array}$ & Rhatany & $\begin{array}{l}\text { Cuminum } \\
\text { cyminum }\end{array}$ & $\begin{array}{c}\text { Pimpinella } \\
\text { anisum }\end{array}$ & Asafoetida & $\begin{array}{c}\text { Saussurea } \\
\text { costus }\end{array}$ & & & \\
\hline \multirow{3}{*}{ Streptococcus } & Hot & 22 & 0 & 0 & 0 & 11 & 25 & 0 & 16 & \multirow{3}{*}{31} & \multirow{3}{*}{0} & \multirow{3}{*}{0} \\
\hline & cold & 15 & 0 & 0 & 30 & 19 & 30 & 35 & 14 & & & \\
\hline & Alcoh. & 0 & 33 & 14 & 0 & 0 & 20 & 30 & 0 & & & \\
\hline \multirow{3}{*}{ Salmonella } & hot & 17 & 0 & 0 & 0 & 32 & 15 & 0 & 25 & \multirow{3}{*}{34} & \multirow{3}{*}{0} & \multirow{3}{*}{0} \\
\hline & cold & 14 & 0 & 0 & 35 & 35 & 0 & 29 & 31 & & & \\
\hline & Alcoh. & 0 & 31 & 0 & 20 & 17 & 0 & 25 & 20 & & & \\
\hline \multirow{3}{*}{ Klebsiellak } & hot & 22 & 21 & 0 & 0 & 20 & 0 & 21 & 25 & \multirow{3}{*}{33} & \multirow{3}{*}{0} & \multirow{3}{*}{0} \\
\hline & cold & 24 & 0 & 0 & 32 & 22 & 30 & 26 & 30 & & & \\
\hline & Alcoh. & 19 & 30 & 0 & 25 & 0 & 25 & 23 & 20 & & & \\
\hline \multirow{3}{*}{ E. coli } & hot & 19 & 0 & 0 & 0 & 12 & 0 & 15 & 31 & \multirow{3}{*}{35} & \multirow{3}{*}{0} & \multirow{3}{*}{0} \\
\hline & cold & 26 & 0 & 0 & 26 & 16 & 32 & 27 & 21 & & & \\
\hline & Alcoh. & 12 & 32 & 0 & 0 & 0 & 21 & 21 & 20 & & & \\
\hline \multirow{3}{*}{ C. albicans } & hot & 32 & 0 & 0 & 25 & 12 & 19 & 15 & 0 & \multirow{3}{*}{0} & \multirow{3}{*}{16} & \multirow{3}{*}{0} \\
\hline & cold & 25 & 0 & 0 & 35 & 19 & 21 & 25 & 16 & & & \\
\hline & Alcoh. & 20 & 30 & 17 & 0 & 0 & 20 & 30 & 0 & & & \\
\hline
\end{tabular}

(+ = with clear zone, - = no clear zone)(all inhibitory zone by $\mathrm{mm}$ )

Table 1: Antimicrobial activity of aqueous and alcoholic herbal and plants extracts against some pathogens.

This examination of antimicrobial effect was performed on 8 chose restorative herbs and plants (Table 1). The screening step in the extracts for antimicrobial action was the on Agar Diffusion Method. This test was utilized so 


\section{Open Access Journal of Veterinary Science \& Research}

as to decide antimicrobial effect of hot and cold aqueous extracts in addition to alcoholic one. The distance across of the inhibitory zone showed the restraint effect. Every tried plant and herbs demonstrated antibacterial impact against examined pathogenic microorganisms particularly Rhatany,
Asafoetida, Lichen, and Pimpinella anisum. The lesser impact was for Coffee peel .Also the most antifungal action against Candida albicans was for Rhatany. For the most part the powerful extract was the cold aqueous for all inspected herbs and plants.

\begin{tabular}{|c|c|c|c|c|c|c|c|c|c|c|c|c|}
\hline \multirow{2}{*}{ Isolates } & \multirow{2}{*}{$\begin{array}{c}\text { aqueous } \\
\text { and } \\
\text { solvent } \\
\text { extracts }\end{array}$} & \multicolumn{8}{|c|}{ Examined Herbs and Plants } & \multirow{2}{*}{\begin{tabular}{|c|}
$\begin{array}{c}\text { Antibacterial } \\
\text { control } \\
\text { positive }\end{array}$ \\
ciprofloxacin \\
\end{tabular}} & \multirow{2}{*}{\begin{tabular}{|c|}
$\begin{array}{c}\text { Antifungal } \\
\text { control } \\
\text { positive }\end{array}$ \\
Nystatin
\end{tabular}} & \multirow{2}{*}{\begin{tabular}{|c}
$\begin{array}{c}\text { Antimicrobial } \\
\text { control } \\
\text { negative }\end{array}$ \\
$\begin{array}{c}\text { Distilled } \\
\text { water }\end{array}$ \\
\end{tabular}} \\
\hline & & Boswellia & Lichen & $\begin{array}{c}\text { Coffea } \\
\text { peel }\end{array}$ & Rhatany & $\begin{array}{l}\text { Cuminum } \\
\text { cyminum }\end{array}$ & $\begin{array}{c}\text { Pimpinella } \\
\text { anisum }\end{array}$ & Asafoetida & $\begin{array}{c}\text { Saussurea } \\
\text { costus }\end{array}$ & & & \\
\hline \multirow{3}{*}{ Streptococcus } & Hot & 22 & 0 & 0 & 0 & 11 & 25 & 0 & 16 & \multirow{3}{*}{31} & \multirow{3}{*}{0} & \multirow{3}{*}{0} \\
\hline & Cold & 15 & 0 & 0 & 30 & 19 & 30 & 35 & 14 & & & \\
\hline & Alcoh. & 0 & 33 & 14 & 0 & 0 & 20 & 30 & 0 & & & \\
\hline
\end{tabular}

Table 2: Antimicrobial activity of aqueous and alcoholic herbal and plants extracts against Streptococcus.

Table 2 shown that the most effective antimicrobial against Streptococcus was Asafoetida extract especially the cold aqueous extract followed by Pimpinella anisum, Rhatany,
Lichen, Boswellia, Cuminum cyminum, Saussurea costus and Coffee peel.

\begin{tabular}{|c|c|c|c|c|c|c|c|c|c|c|c|c|}
\hline \multirow{2}{*}{ Isolates } & \multirow{2}{*}{$\begin{array}{c}\text { Aqueous } \\
\text { and } \\
\text { solvent } \\
\text { extracts }\end{array}$} & \multicolumn{8}{|c|}{ Examined herbs and plants } & \multirow{2}{*}{\begin{tabular}{|c|}
$\begin{array}{c}\text { Antibacterial } \\
\text { control } \\
\text { positive }\end{array}$ \\
ciprofloxacin \\
\end{tabular}} & \multirow{2}{*}{\begin{tabular}{|c|}
$\begin{array}{c}\text { Antifungal } \\
\text { control } \\
\text { positive }\end{array}$ \\
Nystatin
\end{tabular}} & \multirow{2}{*}{ 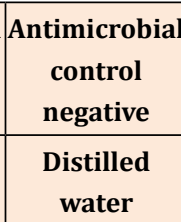 } \\
\hline & & Boswellia & Lichen & $\begin{array}{c}\text { Coffea } \\
\text { peel }\end{array}$ & Rhatany & $\begin{array}{l}\text { Cuminum } \\
\text { cyminum }\end{array}$ & $\begin{array}{c}\text { Pimpinella } \\
\text { anisum }\end{array}$ & Asafoetida & $\begin{array}{c}\text { Saussurea } \\
\text { costus }\end{array}$ & & & \\
\hline \multirow{3}{*}{ Salmonella } & Hot & 17 & 0 & 0 & 0 & 32 & 15 & 0 & 25 & \multirow{3}{*}{34} & \multirow{3}{*}{0} & \multirow{3}{*}{0} \\
\hline & Cold & 14 & 0 & 0 & 35 & 35 & 0 & 29 & 31 & & & \\
\hline & Alcoh. & 0 & 31 & 0 & 20 & 17 & 0 & 25 & 20 & & & \\
\hline
\end{tabular}

Table 3: Antimicrobial activity of aqueous and alcoholic herbal and plants extracts against Salmonella.

Table 3 shown that the most effective antimicrobial against Salmonella was Cuminum cyminum equally with Rhatany extract especially the cold aqueous extract followed by Saussurea costus, equally with Lichen followed by Asafoetida, Boswellia, and Pimpinella anisum, however there is no effect of Coffee peel on it.

\begin{tabular}{|c|c|c|c|c|c|c|c|c|c|c|c|c|}
\hline \multirow{2}{*}{ Isolates } & \multirow{2}{*}{$\begin{array}{l}\text { Aqueous } \\
\text { and } \\
\text { solvent } \\
\text { extracts }\end{array}$} & \multicolumn{8}{|c|}{ Examined herbs and plants } & \multirow{2}{*}{\begin{tabular}{|} 
Antibacterial \\
control \\
positive \\
ciprofloxacin
\end{tabular}} & \multirow{2}{*}{$\begin{array}{c}\text { Antifungal } \\
\text { control } \\
\text { positive } \\
\text { Nystatin }\end{array}$} & \multirow{2}{*}{$\begin{array}{c}\text { Antimicrobial } \\
\text { control } \\
\text { negative }\end{array}$} \\
\hline & & Boswellia & Lichen & $\begin{array}{c}\text { Coffea } \\
\text { peel }\end{array}$ & Rhatany & $\begin{array}{l}\text { Cuminum } \\
\text { cyminum }\end{array}$ & $\begin{array}{c}\text { Pimpinella } \\
\text { anisum }\end{array}$ & Asafoetida & $\begin{array}{c}\text { Saussurea } \\
\text { costus }\end{array}$ & & & \\
\hline \multirow{3}{*}{ Klebsiellak } & Hot & 22 & 21 & 0 & 0 & 20 & 0 & 21 & 25 & \multirow{3}{*}{33} & \multirow{3}{*}{0} & \multirow{3}{*}{0} \\
\hline & Cold & 24 & 0 & 0 & 32 & 22 & 30 & 26 & 30 & & & \\
\hline & Alcoh. & 19 & 30 & 0 & 25 & 0 & 25 & 23 & 20 & & & \\
\hline
\end{tabular}

Table 4: Antimicrobial activity of aqueous and alcoholic herbal and plants extracts against Klebsiella.

Table 4 shown that the most effective antimicrobial against Klebsiella was Rhatany extract especially the cold aqueous extract followed by Saussurea costus, equally with Lichen and Pimpinella anisum followed by Asafoetida, Boswellia and Cuminum cyminum, however there is no effect of Coffee peel on it. 


\section{Open Access Journal of Veterinary Science \& Research}

\begin{tabular}{|c|c|c|c|c|c|c|c|c|c|c|c|c|}
\hline \multirow{2}{*}{ Isolates } & \multirow{2}{*}{$\begin{array}{l}\text { aqueous } \\
\text { and } \\
\text { solvent } \\
\text { extracts }\end{array}$} & \multicolumn{8}{|c|}{ Examined Herbs and Plants } & \multirow{2}{*}{\begin{tabular}{|c|}
$\begin{array}{c}\text { Antibacterial } \\
\text { control } \\
\text { positive }\end{array}$ \\
ciprofloxacin \\
\end{tabular}} & \multirow{2}{*}{\begin{tabular}{|c|}
$\begin{array}{c}\text { Antifungal } \\
\text { control } \\
\text { positive }\end{array}$ \\
Nystatin
\end{tabular}} & \multirow{2}{*}{\begin{tabular}{|c}
$\begin{array}{c}\text { Antimicrobial } \\
\text { control } \\
\text { negative }\end{array}$ \\
Distilled water
\end{tabular}} \\
\hline & & Boswellia & Lichen & $\begin{array}{c}\text { Coffea } \\
\text { peel }\end{array}$ & Rhatany & $\begin{array}{l}\text { Cuminum } \\
\text { cyminum }\end{array}$ & $\begin{array}{c}\text { Pimpinella } \\
\text { anisum }\end{array}$ & Asafoetida & $\begin{array}{c}\text { Saussurea } \\
\text { costus }\end{array}$ & & & \\
\hline \multirow{3}{*}{ E. coli } & Hot & 19 & 0 & 0 & 0 & 12 & 0 & 15 & 31 & \multirow{3}{*}{35} & \multirow{3}{*}{0} & \multirow{3}{*}{0} \\
\hline & Cold & 26 & 0 & 0 & 26 & 16 & 32 & 27 & 21 & & & \\
\hline & Alcoh. & 12 & 32 & 0 & 0 & 0 & 21 & 21 & 20 & & & \\
\hline
\end{tabular}

Table 5: Antimicrobial activity of aqueous and alcoholic herbal and plants extracts against E.coli.

Table 5 shown that the most effective antimicrobial against E.coli Pimpinella anisum equally with Lichen followed by Saussurea costus, Asafoetida, Rhatany equally with
Boswellia followed by Cuminum cyminum, however there is no effect of Coffee peel on it.

\begin{tabular}{|c|c|c|c|c|c|c|c|c|c|c|c|c|}
\hline \multirow{2}{*}{ Isolates } & \multirow{2}{*}{$\begin{array}{c}\text { Aqueous } \\
\text { and solvent } \\
\text { extracts }\end{array}$} & \multicolumn{8}{|c|}{ Examined Herbs and Plants } & \multirow{2}{*}{$\begin{array}{c}\text { Antibacterial } \\
\text { control } \\
\text { positive } \\
\text { ciprofloxacin }\end{array}$} & \multirow{2}{*}{$\begin{array}{c}\text { Antifungal } \\
\text { control } \\
\text { positive } \\
\text { Nystatin }\end{array}$} & \multirow{2}{*}{$\begin{array}{c}\text { Antimicrobial } \\
\text { control } \\
\text { negative }\end{array}$} \\
\hline & & Boswellia & Lichen & $\begin{array}{c}\text { Coffea } \\
\text { peel }\end{array}$ & Rhatany & $\begin{array}{l}\text { Cuminum } \\
\text { cyminum }\end{array}$ & $\begin{array}{c}\text { Pimpinella } \\
\text { anisum }\end{array}$ & Asafoetida & $\begin{array}{c}\text { Saussurea } \\
\text { costus }\end{array}$ & & & \\
\hline \multirow{3}{*}{$\begin{array}{c}C . \\
\text { albicans }\end{array}$} & Hot & 32 & 0 & 0 & 25 & 12 & 19 & 15 & 0 & \multirow{3}{*}{0} & \multirow{3}{*}{16} & \multirow{3}{*}{0} \\
\hline & Cold & 25 & 0 & 0 & 35 & 19 & 21 & 25 & 16 & & & \\
\hline & Alcoh. & 20 & 30 & 17 & 0 & 0 & 20 & 30 & 0 & & & \\
\hline
\end{tabular}

Table 6: Antimicrobial activity of aqueous and alcoholic herbal and plants extracts against C.albicans.

Table 6 shown that the most effective antimicrobial against C.albicans Rhatany followed by Boswellia followed by Asafoetida equally with Lichen followed by Pimpinella anisum, Cuminum cyminum, Saussurea costus and Coffea peel.

\section{Discussion}

There is resurgence in the utilization of natural drugs around the world. An expected 33\% of grown-ups in the Western world utilize elective treatments, including herbs. These herbs might be utilized either in their essential structures or joined in blends. As opposed to compound medications, herbs have here and there been professed to be non-harmful, in light of their regular beginning and long haul use as society drugs. Notwithstanding, issues may emerge because of inherent harmfulness, corruption, replacement, tainting, misidentification, sedate herb co-operations and absence of normalization [23]. This horrible certainty asks the investigation of therapeutic plants and plant inferred mixes utilized in medication and food industry.

Regardless of the advancement of anti-infection agents, bacterial and contagious contaminations are as yet a significant issue in medication, and the nearness of multidrug safe strains represents an extraordinary test. As of late, there has been a developing enthusiasm for normal items because of their accessibility and better biodegradability. In such manner, basic oils may offer an incredible potential and these plant auxiliary metabolites might be utilized as elective enemy of infective and food additives [24].

This study was performed to investigate the antimicrobial activity of some medicinal plant and herbs extracts to Streptococcus, Salmonella, Klebsiella and E. coli) \& fungi ( $C$. albicans).

In late examinations, a few pharmacological and organic exercises of Asafetida have additionally explored and have indicated this oleo gum tar has cell reinforcement, antiviral, antifungal, disease chemopreventive, against diabetic, antispasmodic, hypotensive and molluscicidal impacts [25].Also the fundamental compound of cumin oil is cuminic aldehyde Previous investigations indicated that the antimicrobial and fungitoxic movement could be connected to the principle compound, cuminic aldehyde [26]. Moreover the organic activity of Rhatany is brought about by the astringent rhataniatannic corrosive, which is like tannic acid. Infusions have been utilized as a rinse, a tablet, particularly when blended in with cocaine, as a neighborhood hemostatic and solution for loose bowels [27]. The groupings of caffeine found in coffee removes are sufficient to warrant half of the antimicrobial impact against S. enterica, which is pertinent to human security [28]. Saussurea costus (S. costus) is notable in Islamic medication, which enrolled in the Holy Ahadith said by Prophet Muhammad (Peace 


\section{Open Access Journal of Veterinary Science \& Research}

be upon him) [29]. It is referred to in Arab nations as "AlKost Al-Hindi" and utilized by conventional healers since the period of the Islamic progress. For instance yet not restricted to, S. costus is generally utilized as energizer, sterile, carminative, narcotic, bronchodilator and astringent specialist [30]. The ethanol concentrate of S. lappa (equal S. costus) recorded a wide range antimicrobial action against some human pathogens [31]. Weckessera reported the antibacterial effect of Boswellia dry concentrate and ketoß-boswellic corrosive. Their discoveries uncovered that the concentrate was profoundly compelling against chosen highimpact and anaerobic microbes, for example, Streptococcus, Corynebacteria, C. perfringens and P. acnes; though KBA was not powerful against these pathogens, recommending that the compelling parts are other boswellic acids or basic oils contained in the concentrate [32]. Our results are as per numerous investigations that have provided details regarding the antimicrobial probability of anise against Gram-positive microbes, Gram-negative microscopic organisms, yeast, and filamentous parasites [33-35].

Considering the above results, Table 2 shown that the most effective antimicrobial against Streptococcus was Asafoetida extract especially the cold aqueous extract followed by Pimpinella anisum, Rhatany, Lichen, Boswellia, Cuminum cyminum, Saussurea costus and Coffea peel.

Table 3 shown that the most effective antimicrobial against Salmonella was Cuminum cyminum equally with Rhatany extract especially the cold aqueous extract followed by Saussurea costus, equally with Lichen followed by Asafoetida, Boswellia and Pimpinella anisum, however there is no effect of Coffea peel on it.

Table 4 shown that the most effective antimicrobial against Klebsiella was Rhatany extract especially the cold aqueous extract followed by Saussurea costus, equally with Lichen and Pimpinella anisum followed by Asafoetida, Boswellia and Cuminum cyminum, however there is no effect of Coffea peel on it.

Table 5 shown that the most effective antimicrobial against E.coli Pimpinella anisum equally with Lichen followed by Saussurea costus, Asafoetida, Rhatany equally with Boswellia followed by Cuminum cyminum, however there is no effect of Coffea peel on it.

Table 6 shown that the most effective antimicrobial against C.albicans Rhatany followed by Boswellia followed by Asafoetida equally with Lichen followed by Pimpinella anisum, Cuminum cyminum, Saussurea costus and Coffea peel.

There are number of reports accessible in writing expressing the affectability of different microscopic organisms towards these herbs and flavors utilized in food arrangements [36]. The majority of these investigations include extraction of the dynamic part in the herbs utilizing natural solvents. Be that as it may, herbs as utilized in society medication, the antibacterial properties utilizing natural dissolvable extraction ought not be a rule; in this way, in the current investigation the usually utilized herbs extricates are made with distilled water and alcoholic one tried for its antimicrobial impact against Streptococcus, Salmonella, Klebsiella and E. coli) and fungi (C. albicans). Practically all plants utilized in the conventional medication showed moderate antimicrobial exercises when tried separately as announced before [37]

Dissolvable sorts may likewise influence the natural exercises of the concentrates. Solvents vary in the extraction capacities relying upon their extremity and on the solute's compound structure. Diverse dissolvable concentrates have distinctive solvent phytoconstituents in various sums and consequently, they have fluctuating degrees of organic exercises. In the current study, All tested plants and herbs showed antibacterial effect against examined pathogenic bacteria especially Rhatany, Asafoetida, Lichen, and Pimpinella anisum. The lesser effect was for Coffee peel .Also the most antifungal activity against Candida albicanswas for Rhatany. Mostly the effective extract was the cold aqueous for all examined herbs and plants.

Subsequently, research around there ought to be centered on the advancement of filtration and applications to get viable antimicrobial action at adequately low focuses so as not to unfavorably impact the wellbeing.

Additionally this investigation proposed that herbs with one of kind compound com-pounds that can either restrain the development of pathogens or murder them considered as possible possibility for growing new antimicrobial medications.

\section{Conclusions}

All tested plants and herbs showed antibacterial effect against examind pathogenic bacteria especially Rhatany, Asafoetida, Lichen and Pimpinella anisum. The lesser effect was for Coffea peel. Also the most antifungal activity against Candida albicans was for Rhatany. Mostly the effective extract was the cold aqueous for all examined herbs and plants. Further examinations on dynamic compound identification and reasonable cleansing of these therapeutic plants are proposed. with the expansion of the familiarity with animals utilizing these herbs as treatment by the reasonable sanitization technique to utilize these herbs to be progressively successful with taking in thought that there are some profoundly pathogenic strains which have 


\section{Open Access Journal of Veterinary Science \& Research}

high protection from a great deal of anti-infection agents even the treatment with these herbs. These outcomes add backing to the guaranteed old stories utilization of these plants for a portion of the referenced remedial purposes. The point by point fractionation, disengagement of the dynamic constituents and their poisonousness contemplates are in any case, important to legitimize the protected utilization of these natural medications for animals.

\section{References}

1. Parastoo Karimi Alavijeh, Parisa Karimi Alavijeh, Devindra Sharma (2012) A study of antimicrobial activity of few medicinal herbs. Asian Journal of Plant Science and Research 2(4): 496-502.

2. Piddock KJV, Wise R (1989) Mechanism of resistance of quinolones and clinical perspective. Journal of Antimicrobial chemotherapy 23(4): 475-483.

3. Singh M, Chaudhry MA, Yadava JNS, Sanyal SC (1992) The spectrum of antibiotic resistance in human and veterinary isolates of E.coli collected from 1984-1986 in northern India. J Antimicrobial Chemotherapy 29(2): 159-168.

4. Mulligen ME, Kauffman CA, Yu VL (1993) Methecillin resistant Staphylococcus aureus. American Journal of medicine 94: 313-328.

5. Weeks A, Daly DC, Simpson BB (2005) The phylogenetic history and biogeography of the frankincense and myrrh family (Burseraceae) based on nuclear and chloroplast sequence data. Molecular Phylogenetics and Evolution 35(1): 85-101

6. Spribille Toby, Tuovinen Veera, Resl Philipp, Vanderpool Dan, Wolinski Heimo, et al. (2016) Basidiomycete yeasts in the cortex of ascomycete macroLichens. Science 353(6298): 488-492.

7. (2014) What is a Lichen? Australian National Botanic Gardens.

8. Brodo Irwin M, Duran Sharnoff Sylvia (2001) Lichens of North America. Yale University Press.

9. Margulis Lynn, Barreno EVA (2003) Looking at Lichens. Bio Science 53(8): 776.

10. Bustinza, F (1952) Antibacterial Substances from Lichens. Economic Botany 6(4): 402-406.

11. (2018) Coffee Plant: Arabica and Robusta. Coffee Research Institute.

12. Nazari ZE, Iranshahi M (2011) Biologically active sesquiterpene coumarins from Ferula species. Phytother Res 25:315-323.

13. Iranshahi M (2011) Traditional uses, phytochemistry and pharmacology of Asafoetida (Ferula assa-foetida oleogum-resin)- a review. J Ethnopharmacol 134: 1-10.

14. (2015) Saussurea costus (Falc.) Lipsch. The Plant List v.1.1., Royal Botanic Gardens, Kew and Missouri Botanical Garden.

15. (2008) Saussurea costus. Germplasm Resources Information Network (GRIN), Agricultural Research Service (ARS), United States Department of Agriculture (USDA).

16. (2011) Genus: Krameria L. Germplasm Resources Information Network, United States Department of Agriculture.

17. Simpson BB (1982) Krameria (Krameriaceae) flowers: Orientation and elaiophore morphology. Taxon 31(3): 517-528.

18. Philip R Ashurst (1999) Food Flavorings. Springer, pp: 33.

19. JS Pruthi (1976) Spices and Condiments, National Book Trust, New Delhi, pp: 19.

20. "Cuminum cyminum". Germplasm Resources Information Network (GRIN). Agricultural Research Service (ARS), United States Department of Agriculture (USDA).

21. Akhondzadeh $\mathrm{S}$, Noroozian M, Mohammadi M, Ohadinia S, Jamshidi AH, et al. (2003) Salvia officinalis extract in the treatment of patients with mild to moderate Alzheimer's disease: a double blind, randomized and placebo-controlled trial. J Clin Pharm Ther 28(1): 53-59.

22. Zaika L (1988) Spices and herbs: their antimicrobial activity and its determination. J of Food Safety 9: 97-118.

23. Parrotta JA (2001) Healing plants of peninsular India. A.B. International Wallingford, UK, pp: 944.

24. Lewis $\mathrm{R}$ (1995) The rise of antibiotic-resistant infections, FDA Consumer Magazine 29(7): 5-11.

25. Iranshahi M (2011) Traditional uses, phytochemistry and pharmacology of Asafoetida (Ferula assa-foetida oleogum-resin)- a review. J Ethnopharmacol 134: 1-10.

26. Jacobellis NS, Lo Cantore P, Capasso F, Senatore F (2005) Antibacterial activity of Cuminum cyminum L. and Carum carvi L. essential oils. Journal of Agricultural and 


\section{Open Access Journal of Veterinary Science \& Research}

Food Chemistry 53: 57-61.

27. Chisholm Hugh (1911) Rhatany. Encyclopædia Britannica. 7 (11 ${ }^{\text {th }}$ (Edn.), Cambridge University Press, pp: 231.

28. Ana Amélia P Almeida 1, Adriana Farah, Daniela A M Silva, Elzíria A Nunan, M Beatriz A Glória (2006) (Antibacterial Activity of Coffee Extracts and Selected Coffee Chemical Compounds Against Enterobacteria) J Agric Food Chem 54(23): 8738-8743.

29. Ahmad M, Khan MA, Marwat SK, Zafar M, Khan MA (2009) Useful Medicinal Flora Enlisted in Holy Quran and Ahadith. American-Eurasian J Agric Environ Sci 5(1): 126-140.

30. Hasson SSA, Al-Balushi MS, Alharthy K, Al-Busaidi JZ, Aldaihani MS, et al. (2013) Evaluation of anti-resistant activity of Auklandia (Saussurea lappa) root against some human pathogens. Asian Pac J Trop Biomed 3(7): 557-562.

31. Wani BA, Wani FM, Khan A, Bodha RH, Mohiddin F, et al. (2011) Some herbs mentioned in the Holy Quran and Ahadith and their medicinal importance in contemporary times. J Pharm Res 4(11): 3888-3891.
32. Weckessera S, Engela K, Simon-Haarhausa B, Wittmerb A, Pelzb K, et al. (2007) Screening of plant extracts for antimicrobial activity against bacteria and yeasts with dermatological relevance. Phytomedicine 14(7-8): 508516.

33. Kosalec V, Pepeljnjak S, Kutrak D (2005) Antifungal activity of fluid extract and essential oil from anise fruits (Pimpinella anisum L., Apiaceae). Acta Pharm 55(4): 377-385.

34. Mohamed HSAA, Abdelgadir WS, Almagbou AZI (2015) In vitro antimicrobial activity of Anise seed (Pimpinella anisum L.). Int J Adv Res 3: 359-367

35. Salim RA, Yahi S, Elyass HM (2016) Histology, phytochemistry and bacterial activity of anise (Pimpinella anisum L.) seed and essential oil. J Bacteriol Mycol Open Access 3: 00070

36. Lawless J (2002) The Encyclopedia of Essential Oils. Harper Collins, pp: 135.

37. Rios JL, MC Recio (2005) Medicinal plants and antimicrobial activity. J Ethnopharmacol 100(1-2): 8084.

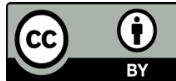

